\title{
Indonesia Membership on Asia-Pacific Space Cooperation Organization (APSCO): Cost and Benefit Analysis
}

\section{Husni Nasution, Shinta Rahma Diana, Bernhard Sianipar, Sri Rubiyanti, Dini Susanti, Astri Rafikasari}

\author{
Pusat Kajian Kebijakan Penerbangan dan Antariksa (Pusat \\ $K K P A)$ \\ Lembaga Penerbangan dan Antariksa Nasional (LAPAN)
}

\begin{abstract}
Indonesia and seven other countries, namely Bangladesh, China, Iran, Mongolia, Pakistan, Peru, and Thailand are the signatory countries of APSCO Convention on October $28^{\text {th }}, 2005$. APSCO is a space cooperation organization outside the United Nations system for Asia Pacific region, initiated by the People's Republic of China. To date from eight signatory countries, only Indonesia has not ratified it yet and has not become a full member, of APSCO. This paper examines the costs and benefits of the Indonesia's membership on APSCO. The methods used are quantitative and qualitative method, while the analysis utilised approaches related to contribution of cost and benefits received by Indonesia, as well as the national interests. mentioned in Presidential Decree No:64/1999 on Indonesian Membership and Indonesian Government Contributions to International Organizations. From the study, it is found that by ratifying the Convention and following APSCO activities optimally, the benefits shall be greater than contribution to APSCO. Similarly, by joining APSCO, it will also provide substantial benefits for our national interest, especially for politics, economy, international peace and security, humanity, and others. It also enhances relationship among countries in the Asia-Pacific region.
\end{abstract}

Keywords: Indonesia, APSCO, Contribution, Benefit, National Interest

Indonesia bersama tujuh negara lainnya, yaitu Bangladesh, Tiongkok, Iran, Mongolia, Pakistan, Peru, dan Thailand adalah negara-negara penandatangan Konvensi APSCO, pada tanggal 28 Oktober 2005 . AP$S C O$ adalah organisasi kerja sama keantariksaan di luar sistem PBB untuk wilayah Asia Pasifik yang diinisiasi oleh Republik Rakyat Tiongkok. Sampai saat ini, dari delapan negara penandatangan, hanya Indonesia yang belum meratifikasi dan belum menjadi anggota penuh APSCO. Tulisan ini mengkaji biaya dan manfaat keanggotaan Indonesia pada APSCO. Metode yang digunakan adalah metode kualitatif dan kuantitatif, sedangkan analisis menggunakan pendekatan yang berkaitan dengan kontribusi.biaya yang diberikan dan manfaat yang diterima bagi kepentingan nasional sèbagaimana disebutkan di dalam Peraturan Presiden RI Nomor. 64 Tahun 1999 tentang Keanggotaan Indonesia dan Kontribusi Pemerintah Indonesia Pada Organisasi Internasional. Dari kajian ditemukan bahwa dengan meratifikasi Konvensi dan mengikuti kegiatan APSCO secara optimal maka manfaat yang diterima oleh. Indonesia akan lebih besar dibandingkan dengan kontribusi yang diberikan kepada APSCO. Bergabungnya Indonesia dalam APSSCO juga akan memberikan manfaat yang berarti bagi kepentingan nasional, khususnya bagi kepentingạn politik, ekonomi, keamanan dan perdamaian internasional, kemanusiaan, dan kepentingan lainnya, serta sekaligus dapat meningkatkan hubungan yang lebih baik sesama negara-negara di kawasan Asia-Pasifik.

Kata kunci: Indonesia, APSCO, Kontribusi, Manfaat, Kepentingan Nasional 
Asia-Pacific Space Cooperation Organization (APSCO) is a space organization outside the United Nations system for the Asia-Pacific region, which was initiated by the People's Republic of China. APSCO began with the establishment of the Asia-Pacific Multilateral Cooperation in Space Technology and Application (AP-MCSTA) by China, Pakistan, and Thailand in Beijing in 1992 (Surat Kedutaan Besar Republik Indonesia Beijing Ke Menteri Luar Negeri RI dan Kepala LAPAN 2015). AP-MCSTA aims to establish cooperations between countries in Asia-Pacific region in the application and development of space technology, as well as forming an institution as a forum for such cooperation. In an effort to establish APSCO, the AP-MCSTA has several times held meetings. In the various meeting, Indonesia was represented by the National Institute of Aeronautics and Space (LAPAN) as the vocal point agency in the field of space, and the Ministry of Foreign Affairs of the Republic of Indonesia. At the signing meeting held on Beijing, October 27 to 29, 2005, Indonesia signed the APSCO Convention on October $28^{\text {th }}, 2005$ along with seven other countries, namely Bangladesh, China, Iran, Mongolia, Pakistan, Peru, and Thailand. These seven countries have ratified the Convention of APSCO as a full member, later followed by Turkey signing and ratifying it. So far, from the eight initial signatory countries plus Turkey, only Indonesia has not yet ratified the Convention of APSCO.

The goals of the organization of APSCO as mentioned in Article 4 of the Convention of APSCO are: (1) improve and strengthen spece cooperation programs among the member countries by establishing a basis for cooperation in the application of space science and technology for feaceful purposes; (2) undertake effective measures to assist the member countires in areas such as research and development of space technology, application and training by formulating and implementing space development policies; (3) increase cooperation, joint development, and share the results among member countries in space technology and its application and space science research by uniting the potential of cooperation in the region; (4) increase cooperation between enterprises and relevant institutions of member countries and improve the industrialization of space technology and its applications; and (5) contribute to the peaceful use of outer space in the activities of international cooperation in the field of space technology and its applications. 
The areas of cooperation as contained in Article 6 the Convention of APSCO in 2005 are as follows: (1) space technology and its application; (2) earth observation, disaster management, environmental protection, satellite communications, satellite navigation and positioning; (3) research space science; (4) education, training and exchange of scientist/ technologist; (5) the establishment of a central data bank for programs of organizational development and dissemination of technical information and other information related to the activities program of the organization; and (6) other cooperation programs based on the agreement of member countries.

Indonesia, represented by LAPAN, are eager to ratify the Convention and become a member of APSCO as the other 8 countries. This is in line with the mandate of Law of Republic of Indonesia Number 21 Year 2013 on Space, Article 29 Paragraph (2) that the government is obliged to seek technology transfer through international cooperation. It is recognized that space technology is a high-tech, high-cost, and high risk. Therefore, it is unlikely that Indonesia will build and develop their own space technology. Cooperation is needed, as noted by Budiman (1995), so the implementation of development will be influenced by external factors, although it is not absolute because internal factors also participate. Aminullah (2004) added that the development of technolgy is a systemic mutual influence between elements of technology development, namely users, providers, advocates, and environment. In general, technology development process is influenced by environmental factors, both internal and external. External factors refer to the technology of other countries, while the internal factors refer to available resources. Meanwhile, Corrrell and Peter (2005) mentioned that international cooperation in space activities allows rationalizing and optimizing resources and mounting missions that would otherwise not be possible. He also says that international cooperation expands the scope of programmes beyond the individual participants. Capabilities by tapping into the resources of multiple countries and enlarges the spectrum of possible mission. This expansion of resources made available through cooperation is not only financial, but also scientific and technological.

If Indonesia ratifies the Convention and becomes a full member of APSCO, Indonesia will be able to play an active role and follow all activities undertaken within APSCO. However, Indonesia is re- 
quired to make an annual contribution as mentioned in Article 18 of the Convention APSCO, that budget spent for APSCO organization comprised of administrative expenditure and the budget for basic activities. To fund these activities, both administration and financial arrangements consist of these basic activities: (1) funding for the organization will be sourced from the contributions of member countries, voluntary help host countries and other members, contributions/subsidies received from other organizations, and services provided to other parties; (2) each member state will contribute to the funding organization in accordance with financing arrangements set out by the council; (3) the Council, by consensus, will decide the scale of financial contributions of each member state, and will be reviewed every three years; (4) scale funding contribution of each member state will be set in accordance with the level of economic development and GDP per capita on average; (5) each member is required to contribute a minimum of funding, called the floor, to the organization, which will be determined by the Board with a majority of two-thirds; (6) no member state will pay a financial contribution of more than $18 \%$ of the total budget of the organization that has been approved; and (7) based on directives given council, the Secretary-General to accept donations, gifts or inheritance (legacies) for the organization as far as it is not contrary to the purpose of the organization.

On the other hand, Presidential Decree No. 64/1999 on Indonesian Membership and Indonesian Government Contributions to International Organizations, Articles $3 \mathrm{a}$ and $3 \mathrm{~b}$ mention that to be a member of international organizations, it is necessary to consider the benefits to be gained and the contributions to be paid to the organization. The intended benefits are benefits that are in line with Indonesia's national interests in supporting development in Indonesia. Therefore, a study on Indonesia's membership in APSCO needs to be done. The study covers how much contribution and benefits will be obtained by Indonesia for its national interest.

\section{Analytical Framework}

To know the amount of annual contribution that will be given by 
Indonesia to APSCO, the contribution scale of member countries which have been determined by APSCO is used, with the formula:

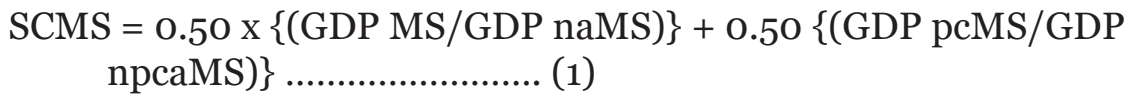
with:

$$
\begin{aligned}
& \text { SCMS }=\text { Scale Contribution of Member States } \\
& \text { GDP }=\text { Gross Domestic Product } \\
& \text { naMS }=\text { number all Member States } \\
& \text { pcMS }=\text { per capitas Member States } \\
& \text { npaMS }=\text { number per capita all Member States }
\end{aligned}
$$

The benefits gained by Indonesia when entering into member of APSCO will be seen from all benefits, both tangible and intangible benefits, direct and indirect. Tangible benefits are gained from the return of the contributions from staff salary and basic activities. On the other hand, intangible benefits will be seen as stipulated in Article 4 of Presidential Decree No. 64/1999 on the Membership and Contributions Government of Indonesia on International Organizations. The intangible benefits referred are the benefits to be gained by Indonesia in its membership or cooperation on APSCO for national interests. Kindleberger (1993) mentioned the relationship or cooperation between countries related to the national interest, that:

“.... the relationship between countries is created due to differences in the advantages that each country has in producing. This comparative advantage opens the opportunity for the specialization chosen by each country to support national development according to the national interest ... “6

According to the authors, the differences of advantages in producing as mentioned by Kindleberger above is the advantage of each member's capability in space science and technology that can be utilized 
by Indonesia for its national interest. Papp (1988) also mentioned that national interest is based on several aspects, such as economic, ideology, military and security, and morality and legality. These aspects are in line with the benefits to be considered for the Indonesia's national interest in its membership at APSCO, as mentioned in Article 4 of Presidential Decree No. 64/1999. However, in this study, the author restricts on the political, economic, international peace and seurity, humanity, and other aspects.

\section{Methodology}

The method employed was descriptive-qualitative analysis. The data used are secondary data, obtained from literature studies in various media, both printed and electronic. The data are then processed by descriptive method as proposed by Punaji (2010). The method was intended to describe a situation, event, object, or anything related to variables explainable by numbers or words. The analysis was conducted qualitatively. The goal, as mentioned by Cresswel and Vicki (2007), was to find some characteristic of the object being analyzed. Analysis is repeated and continued between data collection and analysis, both during and after data collection.

Meanwile, cost and benefit analysis was conducted using the formula given by APSCO and cost and benefit analysis concepts (cost benefit analysis-CBA). CBA was a neoclassical comparative static framework (Makkie, 2010). Decision making paradigm through CBA took costs and benefits into account and it would deemed feasible if the benefits outweigh the costs incurred. The decision becomes unfeasible when the costs outweigh the benefits; hence, CBA is deemed to fail. In general, recommendations are given if benefit increases and cost decreases. There were exceptions for cases within ethical framework using cost and benefit's measurement results which were not recommendable, because for basic decision-making, other possible factors were also considered (Laporan Kegiatan Pengkajian Biaya dan Manfaat Keanggotaan Indonesia pada APSCO 2012). CBA paradigm itself is flexible depending on the description of costs and benefits. Costs and benefits can be and are often defined from various viewpoints or ways, namely: (1) monetary costs and benefits; (2) human costs and benefits; and (3) environmental costs and benefits, etc. According to document of Administrative Rules on Cooperative 
Activities of Asia Pacific Space Cooperation Organization (APSCO), cost analysis consists of capital and recurring costs expected to incur during life cycles of activity. As for both tangible and intangible benefits, they were expected to be direct or indirect.

\section{Results and Discussion}

The costs and benefits analysis is conducted by looking at the financial structure of APSCO. Through APSCO's financial structure (as illustrated in Table 1), it can be seen how big the potential benefits to be gained from APSCO compared to the contributions had been paid. The financial income of APSCO come from member states' contributions, optional project management fee, and other income (interest and tax), While expenditure is used in three categories, namely (i) staff salary; (ii) basic activities; and (iii) administration. Staff salary includes international officials, local staffs, and personnel management documents. Basic activities include activities \& development plan, fundamental researchs, axtending applications, education \& trainings, membership expansion, and network management. Member states' contributions are calculated based on their GDP; thus, APSCO's income are considered costs to the member states. Finally, expenditures are cash outflows to fund activities or programs of APSCO.

One of APSCO's member obligations is to pay annual contributions in the form of money in order to fund basic activities and operations of APSCO Secretariat. Based on some calculations by APSCO, the contribution of each APSCO member for 2015-2017 is shown in Tabel 1.

Table 1. Financial Contribution of Member States of the Year 20152017

\begin{tabular}{|c|l|c|c|c|c|}
\hline \multicolumn{2}{|c|}{ Member States } & $\begin{array}{c}\text { Avarage GDP 3 Years } \\
(2011-2013)\end{array}$ & GDP (\%) & $\begin{array}{c}\text { GDP per Capita } \\
(\%)\end{array}$ & $\begin{array}{c}\text { Contr } \\
(\%)\end{array}$ \\
\hline$(1)$ & \multicolumn{1}{|c|}{$(2)$} & $(3)$ & $(4)$ & $(5)$ & $(6)$ \\
\hline 1. & Bangladesh & 119.265 .372 .121 & 1,06 & 1,75 & 3,00 \\
\hline 2. & China & 8.263 .884 .145 .587 & 73,14 & 13,93 & 18,00 \\
\hline
\end{tabular}




\begin{tabular}{|c|c|c|c|c|c|}
\hline 3. & Iran & 466.686.574.918 & 4,13 & 13,93 & 9,03 \\
\hline 4. & Mongolia & 10.199.934.549 & 0,09 & 8,30 & 4,19 \\
\hline 5 . & Pakistan & 225.063 .672 .652 & 1,99 & 2,86 & 3,00 \\
\hline 6. & Peru & 188.498.547.995 & 1,67 & 14,31 & 7,99 \\
\hline 7. & Thailand & 366.296 .737 .409 & 3,24 & 12,49 & 7,87 \\
\hline 8. & Turkey & 794.608.139.869 & 7,03 & 24,46 & 15,75 \\
\hline 9. & Indonesia & 863.665 .546 .159 & 7,64 & 7,97 & 7,81 \\
\hline & Total & 11.298 .168 .671 .558 & 100 & 100 & 76,63 \\
\hline
\end{tabular}

Source: APSCO

APSCO calculation in Table 1 shows that the contribution of Indonesia in $2015^{-2017}$ is averagely $7.81 \%$. With exchange rate of IDR 13.490 per USD, APSCO budget for $2015-2017$ is USD 4,763,075; USD 4,878,756; and USD 4,990,301 respectively. Thus, Indonesia's contributions in 2015-2017 respectively are IDR 5,018,228,200; IDR 5.140.106.000; and IDR 5,257,626,500.

When Indonesia become a member of APSCO, Indonesia will receive both tangible and intangible benefits. From APSCO's contributions, APSCO members, including Indonesia, can benefit from the return of the contribution from its staff salary and basic activities. Staff salary is obtained when Indonesia becomes Secretary General, the Deputy Secretary General, or other positions. Indonesia can also be a host for APSCO programs. For basic activities, Indonesia will be able to benefit from basic research activities in space regulatory and space law, space science, space technology, and space applications. From basic activities, Indonesia gain more benefits in human resource development (capacity building), including short training course, education degree programs, distance education, international symposia, and many others. In addition, Indonesia also be participated in the cast-exhibitions relating to APSCO program. Costs and benefits are calculated using investment theory approach, where return on investment earned a minimum amount of funds for these investments. 
Costs from member countries' contribution to APSCO are equal to $7.81 \%$, so the benefits gained by Indonesia may at least be $7.81 \%$.

Those benefits can be classified into 3 groups, namely staff salary, basic activities, and administration. Basic calculations are based on the the 3 rd annual data forecast by APSCO. For staff salary, it is assumed that Indonesia at least occupies one seat as a deputy in APSCO board members. For basic activities, at the first stage, they are classified based on liquidity level. Basic activities are firstly grouped into six groups and then divided into three groups, namely fundamental research, education and training, and other expenditures (including group establishment of APSCO and membership). Basic activities are calculated based on basic benefit from the $7.81 \%$ of contributions paid. Moreover, administration is calculated based on the similarly divided administration costs for all member states, because each member has similar responsibility to fund supporting facilities or development costs of the organization. Table 2 shows the calculation results of contribution and benefits if Indonesia ratifies Convention of APSCO based on concepts already described above.

Indonesia can earn some benefits after it paid contribution fee, which is $7.81 \%$ of APSCO budget. APSCO budget was USD 4,878,756 in 2016, so Indonesia should pay USD 381,031. Benefits are derived from the expenditures of USD 339,925 from the salary, basic acivities and administration. Salary benefits are calculated based on the forecast in annual financial report which assumes that one Indonesian staff is placed as a Deputy within APSCO organizaton chart. Based on the calculations, salary benefits are estimated to be around USD 64,265 . While basic activities' benefits are approximately amounted to USD 178,771 , derived from $7.81 \%$ of the total basic activity budgeted at USD 2,289,000. Basic activities is derived from fundamental research amounted to USD 89,425, education \& training of USD 51,546 , and establishment of APSCO and membership expansion of USD 37,80o. Finally, administration benefits are amounted to USD 96,889 .

Table 2. Cost Contribution and Benefits Estimation of Indonesia Membership in APSCO as the Basis to Calculate Benefit from Contribution 


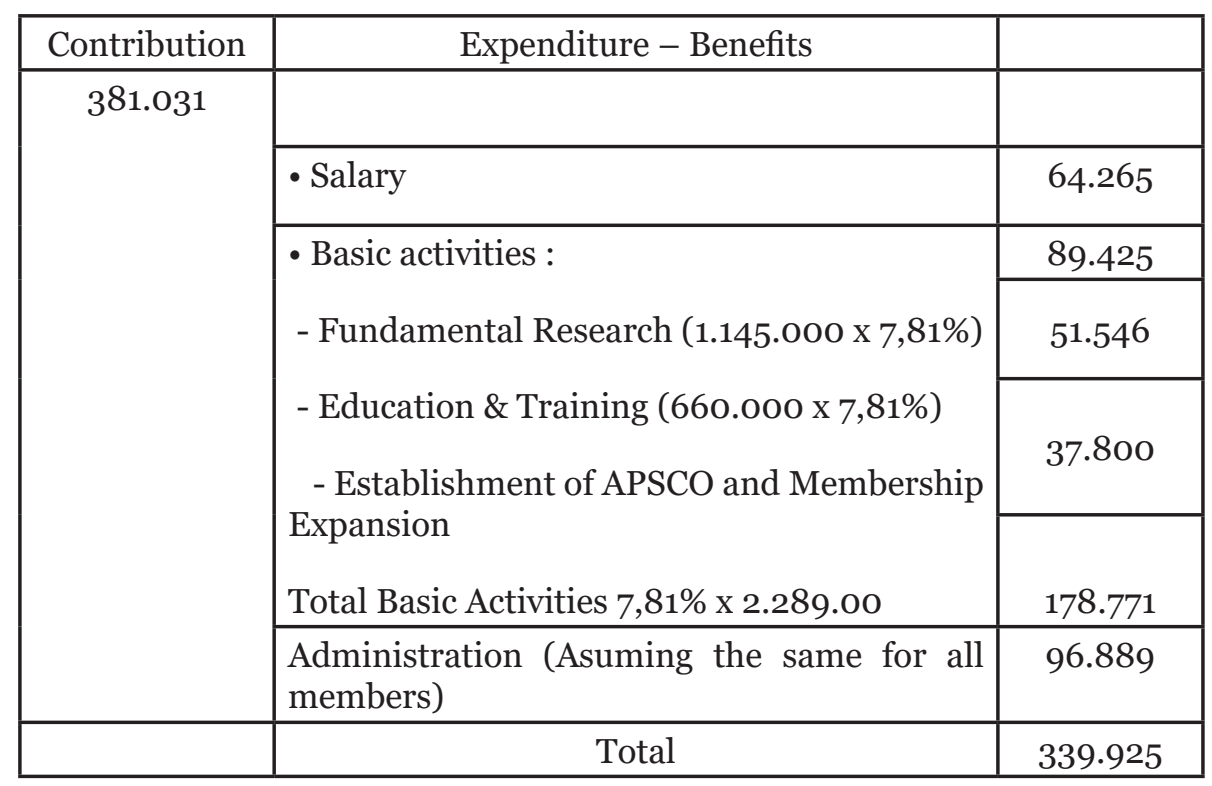

Source: Data Processed

The calculation shows that Indonesia pays contribution amounted to USD 381,031 and receives benefits around USD 339,925. Therefore, from the tangible benefit perspective, Indonesia suffers from a deficit of USD 41,106. It indicates that if Indonesia ratifies APSCO convention, it would benefit a smaller gain than the cost incurred. Judging from APSCO activities, APSCO provides equal opportunities for all member states in utilizing basic activities. Hence, by looking at the trend, contribution and benefits of APSCO is calculated based on sharing similar basic activities programs for all member states. While fixed salary is calculated based on the assumption that Indonesia will put a staff as Deputy. Calculation of costs and benefits on the basis of these considerations are shown in Table 3 .

Table 3. Cost Contribution and Benefit Estimation of Indonesia's Membership in APSCO as Basic Acquisition of Equal Benefits to All Members USD

\begin{tabular}{|l|l|l|}
\hline Contribution & Expenditure - Benefits & \\
\hline
\end{tabular}




\begin{tabular}{|c|c|c|}
\hline \multirow{8}{*}{381.031} & & \\
\hline & - Salary & 64.265 \\
\hline & $\begin{array}{l}\text { - Basic activities: } \\
\text { - Fundamental Research (1.145.0oo: }\end{array}$ & 127.222 \\
\hline & - Education \& Training (660.000: 9 coun- & $73 \cdot 333$ \\
\hline & $\begin{array}{l}\text { - Establishment of APSCO and Member- } \\
\text { ship Expansion }\end{array}$ & 53.777 \\
\hline & Total Basic Activity & 254.332 \\
\hline & $\begin{array}{l}\text { Administration (Asuming the same for all } \\
\text { members) }\end{array}$ & 96.889 \\
\hline & Total & 415.486 \\
\hline
\end{tabular}

Source: Data Processed

Based on Table 3, the estimated benefits are amounted to USD 415,486 , including salary, basic acivities, and administration. Salary benefits are calculated based on the forecast in the annual financial report, assuming that one Indonesian staff is placed as a Deputy in APSCO. Based on the calculation, salary benefit in monetary terms is amounted to USD 64,265. Basic activities' benefit is amounted to USD 254,332 and derived from the acquisition of the same benefits to all member states at USD 2,289,000 for nine member countries. Basic activities are classified into 3 groups of activities, namely fundamental research (USD 127,222), education \& training (USD 73,333), establishment of APSCO and membership expansion (USD 53,777), and administration benefit (USD 96,889).

This study finds that Indonesia's contribution is amounted to USD 381,031 , while the benefits are amounted to USD 415,486. Therefore, based on tangible benefit using APSCO's basic pattern, Indonesia can obtain a surplus amounted to USD 34,455. It indicates that if Indonesia ratifies APSCO, Indonesia gained a greater benefit than the costs incurred. The calculation result shows that Indonesia 
suffered a deficit by $7,81 \%$ (based on the calculation of Secretariat APSCO). However, on the actual calculation based on system implemented by APSCO, each member state has an equal chance to obtain benefit through activities or APSCO program and the result shows that Indonesia could gain a surplus.

The surplus is counted based on the assumption that Indonesia can take maximum advantage of tangible benefits in APSCO programs and occupy one Deputy position in APSCO. Moreover, the estimated surplus of USD 34,455 does not include benefits of data sharing service platform and other intangible benefits. If it is quantified, data sharing service platform can produce benefits of 1000 scenes of satellite data/year (for 2 meters resolution around USD 625/scene or for 0.8 meter resolution around USD 1.560/scene) and estimated needs for each resolution is 500 scenes. With a resolution of 2 meters at a price of USD 625/scene, benefit is approximately amounted to USD 312,500 , while for a resolution of o.8 meters at USD 1,560/ scene, benefit is approximately amounted to USD 780,000. Therefore, total benefit received from data sharing service platform is USD $1,092,500$. The overall calculation of cost and benefits is displayed in Table 4.

Table 4. Cost Contribution and Benefit Estimation of Indonesia's Membership in APSCO by Considering Data Sharing Service

USD

\begin{tabular}{l|l}
$\begin{array}{l}\text { Contr } \\
\text { (Cost) }\end{array}$ & Expenditure (Benefit) \\
\hline
\end{tabular} 


\begin{tabular}{|c|c|c|c|}
\hline \multirow{9}{*}{381.031} & & For Contr & $\begin{array}{l}\text { The Same for } \\
\text { All Countries }\end{array}$ \\
\hline & - Salary & 64.265 & 64.265 \\
\hline & \multirow{5}{*}{$\begin{array}{l}\text { - Basic activities: } \\
\text { - Fundamental Research } \\
\text { - Data sharing service platform } \\
\text { - Education Training for } 4 \text { programs } \\
\text { - Establishment of APSCO and } \\
\text { Membership Expansion } \\
\text { Total Basic Activity } \\
\end{array}$} & 89.425 & 127.222 \\
\hline & & 1.092 .500 & 1.092 .500 \\
\hline & & 51.546 & 73.333 \\
\hline & & 37.800 & 53.777 \\
\hline & & 1.271 .271 & 1.346 .832 \\
\hline & - Administration & 96.889 & 96.889 \\
\hline & Total & 1.432 .425 & 1.507 .986 \\
\hline \multicolumn{2}{|c|}{$\begin{array}{l}\text { Surplus (Defisit) --> Contribution - Expendi- } \\
\text { ture }\end{array}$} & 1.051 .394 & 1.126 .955 \\
\hline
\end{tabular}

Source: Data Processed

Table 4 shows cost contribution and benefit estimation of Indonesia membership in APSCO. The benefit of data sharing service platform is to follow up Presidential Instruction No. 6 Year 2012 on Provision, Use, Quality Control, Processing and Distribution of High Resolution Remote Sensing Satellite Data. Based on the calculation of cost and benefit above, the actual benefit can be obtained by reducing the percentage of contributions paid by the member states if a new member joins APSCO. However, if APSCO's member does not increase and membership is not counted as benefit, expenditure will not be included in the calculation of costs and benefits. Benefits derived from the expenditures, excluding APSCO establishment and membership, can be seen in Table 5 . The benefits in Table 4 above are tangible benefits. While the intangible benefits are referred to Presidential Decree No. 64 Year 1999 on Indonesian Membership and Government Contributions of the Republic of Indonesia on International Organisations. Article 4 states that the benefits as a member of international organizations consist of ideology, political, economic, socio-cultural, international peace and security, humanitarian, and others. 
Table 5. Cost Contribution and Benefit Estimation of Indonesia Membership in APSCO

USD

\begin{tabular}{|c|c|c|c|}
\hline $\begin{array}{c}\text { Contribution } \\
\text { (Cost) }\end{array}$ & \multicolumn{3}{|c|}{ Expenditure (Benefit) } \\
\hline \multirow{8}{*}{381.031} & & For Contribution & $\begin{array}{l}\text { The Same for } \\
\text { All Countries }\end{array}$ \\
\hline & - Salary & 64.265 & 64.265 \\
\hline & $\begin{array}{l}\text { Basic activities : } \\
\text { - Fundamental Research }\end{array}$ & 89.425 & 127.222 \\
\hline & - Data sharing service platform & 1.092 .500 & 1.092 .500 \\
\hline & $\begin{array}{l}\text { - Education Training for } 4 \text { pro- } \\
\text { grams }\end{array}$ & 51.546 & 73.333 \\
\hline & Total Basic Activity & 1.233 .471 & 1.293 .055 \\
\hline & - Administration & 96.889 & 96.889 \\
\hline & Total & 1.394 .625 & 1.454 .209 \\
\hline Surplus (Defisit & -> Contribution - Expenditure & 1.013 .594 & 1.073 .178 \\
\hline
\end{tabular}

Source: Data Processed

As mentioned above, the authors limit the discussion only on politics, economics, international peace and security, humanity, and others (capacity building and involvement of national industry) benefits. Enhancement of international cooperation aims to make optimum use of various positive potentials of international cooperation and affirmation forums with commitment to world peace. It is an important aspect of Indonesia's membership in international organizations. Based on Presidential Decree No. 64 Year 1999, Indonesia's memberships in international organizations are required to obtain maximum benefits for national interest, based on the applicable legislation and the attention to financial efficiency and state capacity. Indonesia's membership in international organization is expected to benefit politics and able to support the process of democratization, strengthen the unity and integrity, support the creation of social cohesion, enhance understanding and tolerance of differences, promote the establishment of good governance, encourage respect, 
and protection and promotion of Human Rights in Indonesia. Indonesia as a developing country in space technology can use APSCO as connector with other member states to open pathways for bilateral cooperation.

Indonesia's membership in APSCO will certainly enhance bilateral relations between member states, and in turn, improve transfers of space technology. APSCO could facilitate establishment of bilateral cooperations between APSCO member states, such as cooperation between Indonesia and China through National Institute of Aeronautics and Space (LAPAN) and China National Space Agency (CNSA). In addition, APSCO is registered in the United Nations and as a permanent observer in COPUOS, APSCO has an important role in international space activities by actively participating in space activities undertaken by the United Nations. Thus, Indonesia will also have a position and increase international influence in international community. Undoubtedly, it would also increase Indonesia's "national pride" in internasional space activities.

As indicated on Table 1, from the eight countries that have ratified the Convention and have became full members of APSCO, there are three countries with high GDP, namely China, Turkey and Iran. Having a high GDP level indicates high rates of economic growth (Suparmoko 1990). At present, China is the country with the third largest investment in Indonesia, following Singapore and Japan, with a value of about US \$ 1.6 Billion (Soedibjo 2017). While, Iran and Turkey are respectively the 31st and 43th countries with the largest investment in Indonesia (Fauzi 2016).

Multilateral cooperation in APSCO enables Indonesia to gain more trust from other countries to invest in Indonesia. According to the author, three member countries with highest GDP levels also have the ability in space technology. Cooperations in APSCO also open up investment opportunities in Indonesia for joint research that will ease financial burden for research and development activities in aeronautical and astronautical technology through joint venture, joint investment, and many others; for instance, investment opportunities to develop low cost vehicles for small satellite launchings 
and constructions of satellite ground stations. Indonesia shall obtain help through updated data sharing among APSCO members. In this regard, Indonesia can use this to minimize the impact of losses caused by disasters, both natural and human-created disasters. It is expected that minimum losses from earthquakes, volcanoes, tsunamis, landslides, forest fires, and other disasters could be created by developing some mechanism of disaster management and environmental monitoring.

Indonesia could also gain benefits for international peace and security to support maintenance and restoration of peace, security, and international stability. Asia Pacific has a fairly high fluctuations in conflicts and affects the surrounding countries, including Indonesia. The presence of foreign interests, particularly Western (US and allies) countries will affect regional stability, which may not be desired by Bejing. China, as a new force in world politics, can be seen as a balancing agent, both regional and global. China can also maintain relationship ties in the region. Nevertheless, China still regards Indonesia as a country that could play an important role to maintain regional stability; hence, China continues encouraging Indonesia to become a full member of APSCO. The inclusion of Indonesia in APSCO will provide benefits for Indonesia to promote stability in Asia Pacific region together with the other members of APSCO, and it is in line with the Preambule of the Constitution of the Republic of Indonesia Year 1945, which states that Indonesia shall participate in the establishment of world order and lasting peace.

Many programs related to science-technology, satellite, remotesensing, communication, and navigation are included on APSCO programs. Such programs can be applied for various purposes, such as disaster prevention, control efforts, resulting rehabilitation, and human life quality's improvement. As a disaster-prone countries, Indonesia is in dire need of such technology. With the inclusion of Indonesia as a member, the chance of getting these technologies become larger, for instance early warning systems against harmful space weather and potential monitoring space object crashing in Indonesia. Monitoring of the fall of a space object is very important, especially if the object is charged by nuclear power which is harmful for the human race. Moreover, it can also increase capacity building in disaster management and assist the reconstruction and reha- 
bilitation of the affected areas. Member states can gain maximum benefit through multilateral cooperations in research, exploration, development, and implementation of joint development space programs and activities. Joint development reduces risks associated with this space technology. By becoming a member of APSCO, human resources can have trainings or educations, which can be beneficial by others within and outside LAPAN. By becoming a member of APSCO, there is an opportunity for Indonesia to improve private industry involvement in various APSCO projects, as stipulated under the Convention of APSCO, particularly Article 5 on Industrial Policy.

\section{Conclusion}

Based on the results of the study and discussion above, the authors can summarize as follows: (1) If Indonesia join APSCO membership, the benefits gained for the national interest is higher than the contributions paid; (2) If Indonesia join APSCO, it is more convenient for Indonesia to conduct bilateral cooperation with other member countries for other programs that are not included in APSCO (for instance, in rocket launchers vehicle technology development program to support Indonesia's national interest in defense and security); (3) As a signatory state to APSCO's establishment, and if Indonesia ratifies APSCO Convention, it gives a better image for Indonesia at the international level with its consistency; (4) If Indonesia remains as a member of APSCO, it is expected that Indonesia could exploit the opportunities of cooperations and trainings held by APSCO, so that the contributions paid by Indonesia could be beneficial Indonesia's national interest, especially space science and technology development; and (5) Joining APSCO improves relationships between Indonesia and other countries in Asia-Pacific region.

\section{References}

\section{Books}

Aminullah, E., 2004. Berpikir Sistemik. Jakarta: Penerbit PPM. 
Budiman, A., 1995. Teori Pembangunan Dunia Ketiga. Jakarta: PT. Gramedia Pustaka Utama.

Cresswell, John W. dan L. Piano Clark Vicki, 2007. Designing and Conducting Mixed Methods Research. California: Sage Publication.

Kindleberger, Charles P., 1993. Ekonomi Internasional, edisi ketujuh. Jakarta: Erlangga.

Papp, D. S., 1988. Contemporary International Relation: A Framework for Understanding, edisi kedua. New York: MacMillan Publishing Company.

Punaji, S., 2010. Metode Penelitian Pendidikan dan Pengembangan. Jakarta: Penerbit Kencana

Suparmoko, 1990. Ekonomi Pembangunan, Edisi keempat. Yogyakarta: BPFE.

\section{Government Publications}

Keputusan Presiden RI Nomor 64 Tahun 1999 Tentang Keanggotaan Indonesia dan Kontribusi Pemerintah Republik Indonesia Pada Organisasi-Organisasi Internasional, 1999. Jakarta: Kementerian Sekretariat Negara RI.

Laporan Kegiatan Pengkajian Biaya dan Manfaat Keanggotaan Indonesia Pada APSCO, 2012. Jakarta: Bidang Pengkajian Kedirgantaraan Nasional, Pusat Pengkajian dan nformasi Kedirgantaraan, Deputi bidang Sains, Pengkajian dan Informasi Kedirgantaraan, LAPAN.

Surat Kedutaan Besar Republik Indonesia Beijing Ke Menteri Luar Negeri RI dan Kepala LAPAN Nomor: R-oo605/BEIJING/151228, 2015. Jakarta: Pusat Komunikasi Kemlu RI.

Undang-Undang Republik Indonesia Nomor 21 Tahun 2013 Tentang Keantariksaan, 2013. Jakarta: DPR RI.

\section{Online Articles}


Fauzi, Ahmad, 2016. "BKPM: Sektor Energi Jadi Fokus Kerja Sama Indonesia-Iran”, Kompas, 16 Desember [online]. In https:// ekonomi.kompas.com/read/2016/12/16/095811326/bkpm. sektor.energi.jadi.fokus.kerja.sama.indonesia-iran [accessed on January 27, 2017].

Soedibjo, Wisnu, 2017. "Investasi China di Indonesia Capai US \$1,6 Miliar", BKPM [online]. In www.bkpm.go.id [accessed on June, 2017].

\section{Others}

Mackie, Peter J., 2010. "Cost Benefit Analysis in Transport: A UK Perspective”, OECD/ITF Joint Transport Research Centre Discussion Paper, No. 2010-16, 21-22 October. 
Indonesia Membership on Asia-Pacific Space Cooperation Organization (APSCO):

Cost and Benefit Analysis 